\title{
Human Papillomavirus Vaccines: An Updated Review
}

\author{
Liqin Cheng, Yan Wang and Juan Du *
}

Department of Microbiology, Tumor and Cell Biology (MTC), Karolinska Institutet, 17177 Stockholm, Sweden; liqin.cheng@ki.se (L.C.); yan.wang@ki.se (Y.W.)

* Correspondence: Juan.du@ki.se

Received: 29 June 2020; Accepted: 14 July 2020; Published: 16 July 2020

\begin{abstract}
Human papillomavirus (HPV) vaccines, which were introduced in many countries in the past decade, have shown promising results in decreasing HPV infection and related diseases, such as warts and precancerous lesions. In this review, we present the updated information about current HPV vaccines, focusing on vaccine coverage and efficacy. In addition, pan-gender vaccination and current clinical trials are also discussed. Currently, more efforts should be put into increasing the vaccine's coverage, especially in low- and middle-income countries. Provision of education on HPV and vaccination is one of the most important methods to achieve this. Vaccines that target HPV types not included in current vaccines are the next stage in vaccine development. In the future, all HPV-related cancers, such as head and neck cancer, and anal cancer, should be tracked and evaluated, especially in countries that have introduced pan-gender vaccination programs. Therapeutic vaccines, in combination with other cancer treatments, should continue to be investigated.
\end{abstract}

Keywords: human papillomavirus; vaccine; Cervarix; Gardasil; Gardasil 9

\section{Introduction}

Human papillomavirus (HPV) infection, one of the most common sexually transmitted diseases, is associated with cancers such as cervical cancer, head and neck squamous cell carcinoma (HNSCC), and anal cancer [1-3]. To date, more than 200 HPV types have been identified [4,5]. HPV infections are transmitted primarily through skin-to-skin or skin-to-mucosa contact. Some HPV types mainly infect cutaneous tissues and induce warts, while other HPV types mainly target mucosal tissues of cervical and oral tracts $[1,6]$. Depending on the oncogenic potential, various mucosal HPV types are categorized as either high-risk HPV/oncogenic HPV types, which can be potentially carcinogenic, e.g., HPV16, 18, 31, and 33, or low-risk HPV/non-oncogenic HPV types, which are mostly found in warts, e.g., HPV6 and 11 [7,8]. Fortunately, three HPV vaccines were introduced against up to nine HPV types, showing strong protection against cervical infections caused by these HPV types as well as condylomas and some HPV-related cancers [9-15]. There are great reviews on HPV infections and their relation to different cancers, including oropharyngeal, vaginal, vulvar, penile, and anal cancers [1,16-18]. In this review, we focus on HPV vaccines and their effects.

\section{HPV Vaccine Coverage}

Quadrivalent HPV vaccine, Gardasil (Merck \& Co., Kenilworth, NJ, USA), is the first commercially available HPV vaccine licensed by the United States Food and Drug Administration (FDA), in 2006. The bivalent HPV vaccine, Cervarix (GSK, Brentford, UK) was approved by the European Medicines Agency (EMA) in 2007 and by the FDA in 2009 [19]. Cervarix protects against the most common oncogenic genotypes of HPV (types 16 and 18), which cause around 70\% of cervical cancers [20]. Gardasil, in addition to HPV16 and 18, also targets HPV6 and 11, which cause around 90\% of genital warts [21]. In 2014, a nine-valent vaccine, Gardasil 9 (Merck \& Co., Kenilworth, NJ, USA), was licensed 
by the FDA, which offers protection against HPV6, 11, 16, 18, 31, 33, 45, 53, and 58. The five additional types covered by Gardasil 9 could cover HPV types related to another $20 \%$ of cervical cancer cases; thus, Gardasil 9 has the potential to protect against approximately $90 \%$ of cervical cancers [22]. A comparative modeling analysis predicted that if the global strategy of combined intensive scaled-up HPV vaccination and twice-lifetime screening is achieved, the incidence of $97 \%$ cervical cancers would be reduced by 2100 [23].

In general, HPV national programs cover about $30 \%$ of the global target population, with low full-dose coverage in many regions [24]. The HPV vaccine coverage is significantly higher in high-income countries, where about 32\% of females aged 10-20 years received the full-dose vaccination by 2014 [24,25]. HPV coverage is more than $60 \%$ in countries such as Australia, Denmark, and Sweden [24,26,27]. Most low- and middle-income countries remain unprotected, only about $1 \%$ of adolescent females in low-income countries received a full course of HPV vaccines [24]. Fortunately, HPV vaccine was successfully introduced in some low- and middle-income countries' national routine immunization schedules and achieved high coverage, such as in Bhutan and Rwanda [26,28]. The HPV-vaccination gap also exists between urban and rural residents within low- and middle-income countries. For example, although $65.3 \%$ of children are fully immunized in India, the HPV coverage is only $2 \%$ in rural villages of Uttar Pradesh, with $72 \%$ vaccine coverage concentrated in urban areas [29]. As more than $80 \%$ of cervical cancer deaths occur in low- and middle-income countries, the implementation of the HPV vaccine is urgently needed for public health intervention in these countries [25].

\section{Mechanisms of Vaccinations}

Currently, the licensed HPV vaccines are developed based on a virus-like particle (VLP) of the major papillomavirus capsid protein L1 [30]. Since VLPs are merely protein and do not contain viral genome, these are considered non-infectious and non-oncogenic, and thus are safer than HPV-attenuated vaccines [31]. VLPs can be produced in bacteria, yeast, or insect cells. Cervarix comprises HPV16 and 18 VLPs, monophosphoryl lipid A (MPL), and aluminum hydroxide (together called adjuvant system 04, AS04) as an adjuvant [32]. MPL is a toll/like receptor 4 (TLR4) agonist that can induce high levels of antibodies as compared to Gardasil and Gardasil 9, both of which contain only aluminum hydroxide as an adjuvant and are produced in Saccharomyces cerevisiae yeast. Gardasil contains VLPs against HPV6, 11, 16, and 18, while Gardasil 9 contains VLPs against HPV6, 11, 16, 18, 31, 33, 45, 52, and 58 [33]. Table 1 shows the detailed comparison of the three vaccines available in the market.

Table 1. Comparison of HPV vaccines.

\begin{tabular}{|c|c|c|c|c|}
\hline HPV Vaccines & \multicolumn{2}{|c|}{ Cervarix } & Gardasil & Gardasil 9 \\
\hline $\begin{array}{c}\text { Time of FDA } \\
\text { Approval }\end{array}$ & \multicolumn{2}{|c|}{2009} & 2006 & 2014 \\
\hline Manufacture & \multicolumn{2}{|c|}{ GSK } & Merck \& Co & Merck \& Co \\
\hline \multirow{9}{*}{ VLP Types } & 6 & - & $20 \mu \mathrm{g}$ & $30 \mu \mathrm{g}$ \\
\hline & 11 & - & $40 \mu \mathrm{g}$ & $40 \mu \mathrm{g}$ \\
\hline & 16 & $20 \mu \mathrm{g}$ & $40 \mu \mathrm{g}$ & $60 \mu \mathrm{g}$ \\
\hline & 18 & $20 \mu \mathrm{g}$ & $20 \mu \mathrm{g}$ & $40 \mu \mathrm{g}$ \\
\hline & 31 & - & - & $20 \mu \mathrm{g}$ \\
\hline & 33 & - & - & $20 \mu \mathrm{g}$ \\
\hline & 45 & - & - & $20 \mu \mathrm{g}$ \\
\hline & 52 & - & - & $20 \mu \mathrm{g}$ \\
\hline & 58 & - & - & $20 \mu \mathrm{g}$ \\
\hline
\end{tabular}


Table 1. Cont.

\begin{tabular}{cccc}
\hline HPV Vaccines & Cervarix & Gardasil & Gardasil 9 \\
\hline Expression system & Baculovirus -Insect Cell & Yeast & Yeast \\
\hline Adjuvant & $\begin{array}{c}50 \mu \mathrm{g} \mathrm{MPL} \text { absorbed on } 500 \mu \mathrm{g} \\
\text { aluminum hydroxide (AS04) }\end{array}$ & $\begin{array}{c}225 \mu \mathrm{g} \text { aluminum } \\
\text { hydroxyphosphate sulfate }\end{array}$ & $\begin{array}{c}500 \mu \mathrm{g} \text { aluminum } \\
\text { hydroxyphosphate sulfate }\end{array}$ \\
\hline Dose & $0.5 \mathrm{~mL} /$ dose & $0.5 \mathrm{~mL} /$ dose & $0.5 \mathrm{~mL} / \mathrm{dose}$ \\
\hline Injection schedule & $0,1,6$ months & $0,2,6$ months & $0,2,6 \mathrm{months}$ \\
\hline $\begin{array}{l}\text { Cervical cancer } \\
\text { Protection rate }\end{array}$ & $70 \%$ & $70-75 \%$ & $90 \%$ \\
\hline
\end{tabular}

The HPV vaccines currently being produced are based on L1-VLPs, which only provide typerestricted immunity, neglecting many other oncogenic HPV genotypes. Consequently, the secondgeneration VLPs, such as L2-VLP and Chimeric L1-L2 VLP, are drawing a lot of attention for their broader genotype coverage [34,35]. In comparison to L1-VLP, the minor capsid protein, L2, contains type-common epitopes that can provide broad cross-neutralizing antibody responses. Notably, Cervarix can confer a degree of cross-protection against some phylogenetically related types of HPV16 and 18 from the same phylogenetic cluster alpha-9 (HPV16-like: HPV31, 33, 35, 52, 58) and alpha-7 (HPV18-like: HPV39, 45, 59, 68) species groups, owing to its unique adjuvant systems [36].

\section{HPV Vaccine Efficacy}

Cervarix induces high anti-HPV16 and 18 antibody titers and can prevent the incidence of infection for at least 10 years [36,37]. In addition, Cervarix invokes a significantly high and long-term cross-reactive immunogenicity against HPV31 and 45. During a 10-year-follow-up study, over 85\% of participants remained seropositive for anti-HPV31 and 45 antibodies following three doses of Cervarix [37]. In addition, Cervarix efficiently ( $>90 \%$, injection prior to HPV exposure) protects against vaccine-targeted HPV related abnormalities and precancerous lesions, including cervical intraepithelial neoplasia 2 (CIN2), CIN3 and adenocarcinoma in situ (AIS) [38,39]. Cervarix also shows efficacy $(>60 \%)$ in preventing all cervical precancerous lesions regardless of HPV infection or precancerous lesions caused by any HPV types [40,41]. Notably, Cervarix also showed strong protection against oral HPV16 and 18 infections. After a four-year vaccination period, a 93\% reduction in the prevalence of oral HPV16 and 18 infections was reported [10].

Quadrivalent Gardasil shows excellent efficacy against cervical HPV infection, cervical cancer precursor lesions, and genital warts caused by the HPV types covered by Gardasil [9,11]. In addition, studies demonstrated that Gardasil significantly decreases HPV infections in the anus, vulva, and penis, as well as in the oral cavity related to HPV vaccine types [12-14]. Gardasil has a strong prevention rate ( $>90 \%$, injection prior to HPV exposure) against CIN 2 or worse (CIN $2+)$, CIN $3+$ and vulvar/vaginal intraepithelial neoplasia grade 2 or worse (VIN/VaIN 2+), caused by HPV 16 and $18[6,41]$. However, the inhibition on CIN $2+$ and CIN $3+$ caused by any HPV types was lower (20-50\%) [6,41]. Comparatively, Gardasil demonstrated less cross-protection effect than Cervarix and the protection efficacy for HPV31, 33, 45, 52, and 58 were $46 \%, 29 \%, 7 \%, 18 \%$, and $6 \%$, respectively [36,42].

Gardasil 9 can efficiently prevent infections and cervical cancer precursor lesions $(>95 \%$, injection prior to HPV exposure) of any grade related to HPV types covered in the vaccine [15,43,44]. Gardasil 9 also showed around $90 \%$ and $80-85 \%$ inhibition in the incidence of vulvar and vaginal diseases, respectively $[43,45,46]$. A recent study reported that antibodies induced by Gardasil 9 could transfer across the placenta, which potentially protects the infant from HPV6 and 11 infections [47]. For HPV types not covered by the vaccine, Gardasil 9 has low cross-protective efficacy and has little effect on infections and diseases related to HPV types besides the nine vaccine types [44,48].

A recent systematic meta-analysis including 60 million individuals from 14 high-income countries showed that HPV vaccines significantly reduced the prevalence of HPV-related endpoints (genital HPV infections, anogenital wart diagnoses, or histologically confirmed CIN2+) among girls, women, 
and boys [49]. The most common HPV type, HPV16 and 18, significantly decreased by $83 \%$, and HPV31, 33, and 45 decreased by $54 \%$, among girls aged $13-19$ years. The prevalence of anogenital warts decreased by $67 \%$, and CIN2+ decreased by $51 \%$, among girls aged $15-19$ years. In addition to the significant decrease of HPV-related endpoints, herd effects among boys and older women were also observed in this meta-analysis [49].

\section{Effects That Influence the Vaccine Coverage and Efficacy}

There are many potential effects that influence vaccine coverage and efficacy, such as vaccine age, geographical regions, and education. The ideal time for the best protection against HPV-related diseases is prior to HPV exposure [50]. Studies demonstrated that vaccination before first sexual contact could protect more than $90 \%$ of targeted HPV-related infections, abnormalities, and precancerous lesions, while vaccination after HPV exposure only protects about $50-60 \%$ infections [38,40]. Taira et al. developed a disease transmission model and suggested that vaccination of 12 -year-old girls provides the best and most cost-effective solution against cervical cancer [51]. The earlier the HPV vaccination is provided to the population before the sexual-behavior transition, the more effective the results are likely to be [52].

Studies showed HPV types in cancer and vaccine efficacy vary between geographical regions $[45,53,54]$. In squamous cell carcinoma, HPV16 was the predominant type, followed by HPV18, 45, 31, and 33 in many regions except Asia, where HPV58 and 52 were more frequently identified after HPV16 and 18 [54]. As many as $82 \%$ of invasive cervical cancers were related to HPV16 and 18 in Western and Central Asia, compared to $68 \%$ in Eastern Asia [53]. Studies found that Gardasil 9 protects against HPV-types-associated cervical cancers with an efficiency of 92\% in Africa and North America, $91 \%$ in Europe, $90 \%$ in Latin America and the Caribbean, 88\% in Asia, and 87\% in Australia [45,55]. Moreover, ethnic disparities in HPV vaccinations were also found among United States- and foreign-born Hispanics and African Americans [56,57]. A meta-analysis suggested that ethnic minorities in the United States are more likely to initiate but less likely to follow through the full series of HPV vaccination [58].

Women's knowledge and educational interventions prevent HPV transmission, increase the acceptability of HPV vaccine, and thus help to improve HPV vaccine coverage [59-62]. Video education has been reported to increase the willingness to accept the HPV vaccine by about $20 \%$ in young women [61]. Educational videos, outlining the risks of HPV and the benefits of vaccines have been shown to be an efficient way to improve vaccination behaviors [59,60]. In addition, a randomized trial with 30 pediatric and family medicine clinics showed that presumptive announcements led to a 5\% increase in HPV vaccine coverage compared to control clinics [63]. A health care professional communication training intervention significantly improved HPV-vaccine-series initiation $(10 \%)$ and completion (4\%) [64]. All these results suggested a strong influence of educational interventions on HPV vaccine coverage. Therefore, further efforts should be put on promoting awareness of HPV as well as the protection and safety characteristics of HPV vaccinations.

The number of sexual partners, one of the most important risk factors for HPV infection, has also been demonstrated as a strong predictor of CIN 2 and 3 regression [65-69]. Women with no lifetime or past-year sexual partners had significantly lower HPV vaccine initiation as compared with those with male sexual partners [70]. Notably, HPV vaccination did not show any comparative increase in sexual activity between vaccinated and unvaccinated men and women [71].

\section{Male Vaccination}

WHO guidelines recommend HPV vaccination focusing primarily on young girls, as females have 10 times higher risk of HPV-related cancers than males, and heterosexual males will be protected owing to herd immunity caused by high female vaccine coverage $[19,72,73]$. A study from the Netherlands showed that the risk of HPV-associated cancers among men could be reduced by $37 \%$ and $66 \%$ if vaccine uptake among girls reached $60 \%$ and $90 \%$, respectively [72]. However, strong arguments 
emerged for extending vaccination to adolescent boys over the last decade [74]. Female HPV vaccine coverage in many countries is less than $60 \%$, making the protection against males hard to confer. Moreover, indirect protection has minimal effect on homosexual men, putting them at a substantially higher risk of HPV infections and diseases [75].

Men have a higher risk of oral HPV infection and certain HPV-related cancers, which is associated with the number of lifetime oral sexual partners and tobacco use [76-78]. Around 20-30\% of HNSCC and $50 \%$ or more tonsillar carcinoma contained HPV DNA [79-84]. Oncogenic oral HPV DNA was detected in 4\% adults aged 20-69 years, while 8\% of older men aged 50-59 years had oncogenic oral HPV infections [78]. The number of HPV-infection-induced cancer cases of oropharynx, oral cavity, and larynx in men were, respectively, 4, 2, and 7 times higher than female patients, and most of the cases were related to HPV types covered by the current vaccines [2,25]. Nevertheless, HPV infection is found in over $90 \%$ and $75 \%$ anal carcinoma cases among women and men, respectively [85,86]. The most common HPV types found in anal carcinoma are HPV16, 18, 31, 33, and 45, which are all covered by the current Gardasil 9 vaccine $[85,86]$. Some studies have suggested that HPV vaccination could protect against the progression of oral cancers, as oral HPV infection can be effectively inhibited by HPV vaccines [10,12,13]. However, this issue has not been fully addressed owing to the lack of alignment between vaccine availability and the changes in cancer development over time $[87,88]$.

Pan-gender vaccination programs that extend to adolescent boys were implemented in a number of countries, including Australia, Austria, Bermuda, Brazil, Canada, Croatia, England, Germany, Israel, Italy, Lichtenstein, New Zealand, Norway, Serbia, Sweden, and the United States [89]. Some countries, such as England, provide free HPV vaccination to homosexual men too [90]. A study using the population-based single-type HPV transmission model with data from Sweden showed that the catch-up vaccination of males could lead to a reduction of about $17 \%$ in the HPV prevalence when compared with female-only vaccination [75]. Multiple models suggested that vaccinating both men and women is more beneficial in reducing HPV infections and diseases than vaccinating only females, although male vaccination has lower cost-effectiveness than female vaccination [72,75,91-93]. In countries where pan-gender vaccination programs are introduced, studies should be carried out to evaluate the impact of HPV vaccination on HPV-related cancers other than cervical cancer, especially among men.

\section{Vaccine Safety and Adverse Effects}

Multiple studies have demonstrated that all three vaccines exhibit excellent safety and tolerance in different age groups [94-97]. A 10-year-follow-up study showed that Gardasil is immunogenic, clinically effective, and generally well-tolerated in preadolescents and adolescents [98]. Furthermore, Cervarix and Gardasil 9 demonstrate great tolerance and antibody sustenance after vaccination for up to 9.4 years and 6 years, respectively [99]. The most frequent adverse effects (AEs) of Cervarix and Gardasil were injection-site reactions, such as pain and swelling, possibly due to the VLP-related inflammation process [100]. Cervarix can also lead to systemic symptoms, such as fever, nausea, vomiting, dizziness, myalgia, and diarrhea [100]. Headache and fatigue are the most common Cervarix-related systemic AE, seen in approximately 50-60\% participants [101]. Gardasil and Gardasil 9 recipients may also have general symptoms, but no increased risk of systemic symptoms was evident in their recipients [100]. Some scientists proposed a hypothesis between HPV vaccination and small fiber neuropathy and dysautonomia [102]. HPV vaccination period was also found to overlap with post-vaccination symptoms, including chronic regional pain syndrome and autonomic and cognitive dysfunctions [103]. However, the same group later found that the vast majority of the girls that complained about unusual symptoms were initially diagnosed with psychiatric illness. Thus, no causal link has been demonstrated between HPV vaccination and the development of these symptoms [104]. Furthermore, several large meta-analysis studies found no significant observations of serious AEs, pregnancies, medically significant conditions, and new onset of autoimmune diseases after HPV vaccination $[105,106]$. A cohort study, including almost 1 million girls, following Gardasil vaccination 
showed that no serious AEs, such as autoimmunity, neurological, and venous thromboembolic AEs were identified when compared with background rates [107]. Although there were no serious AEs linked to HPV vaccination, more efforts are still needed to adjust the components, such as adjuvants, to mitigate the AEs, without hampering the vaccine efficiency.

\section{Clinical Trials}

National HPV vaccination programs were introduced in some countries more than 10 years ago, allowing surveillance trials to evaluate the long-term impact of vaccine introduction on community settings. A large number of clinical trials are focused on the effectiveness of HPV vaccines against infection and related cancers as well as optimization of the vaccine schedules $[15,18,108,109]$. In phase I-III clinical trials before marketing, all three vaccines showed excellent protection against vaccine-targeted HPV-related infection and pre-lesions of cervical cancer [44,101,110]. Gardasil and Gardasil 9 were efficacious against vaginal, vulvar, and anal dysplasia [11,44,111-113]. A large phase III trial study on Cervarix, called PATRICIA, demonstrated 100\% protection against HPV 16 and 92.3\% protection against HPV18 [114]. Furthermore, other studies on Cervarix have shown a high cross-protection against HPV31 and HPV45, with around 78\% and 81\% efficacy for protection against persistent HPV31 and HPV45 infection, respectively, and a 100\% vaccine efficacy against CIN2+ or adenocarcinoma in situ caused by these two HPV types [114,115]. Gardasil clinical trials, called FUTURE I and FUTURE II, prevented 98\% of HPV 16 and HPV18 related high-grade cervical lesions, if participants had not been previously exposed to either HPV 16 or HPV 18. Especially for HPV18, this vaccine demonstrated a $100 \%$ vaccine efficacy against CIN2+ $[110,111]$. The Gardasil 9 vaccine study (NCT00543543) showed 96\% efficacy in preventing persistent infection and high-grade cervical, vulvar, and vaginal diseases related to HPV31, 33, 45, 52, and 58. Furthermore, it displayed equal efficacy as Gardasil to prevent diseases caused by HPV types 6, 11, 16, and 18 [44]. HPV vaccines also showed strong efficacy against oral HPV infections in a few studies, but whether HPV vaccination can inhibit the progress of HPV related oropharyngeal cancers has not yet been evaluated $[10,12,13]$. More clinical trials are needed to investigate the effect of HPV vaccine programs in inhibiting HPV associated oral, penile, anal, and vulvar diseases.

Herd protection was probably achieved in some countries and a decrease in the HPV prevalence among both vaccinated and non-vaccinated women was observed [27,109,116]. Post-licensure reports from countries with established national HPV vaccine programs demonstrated beneficial effects, at the population level, in the incidence of genital warts and high-grade cervical abnormalities [117-120]. Moreover, as the introduction of HPV vaccination in low- and middle-income countries remains the main challenge in tackling the burden of cervical cancer, alternative approaches such as oneor two-dose schedules are suggested to reduce economic challenges [121,122]. The comparative immunogenicity of two-dose and three-dose HPV-vaccine schedules are reported through antibody responses in young females $[123,124]$.

The results of HPV infection during pregnancy were disputable. Some studies reported a risk of HPV infection, since the hormonal levels may change during pregnancy and alter the immune system [125,126]. Other studies showed that pregnancy does not influence HPV prevalence, incidence, and clearance [127-129]. A recent pooled analysis of clinical trials reported no differences in the prevalence of either oncogenic HPV types or HPV16 and 18 infections in women, before and after pregnancy [108]. More clinical trials are needed to evaluate the interactions between HPV infection and pregnancy.

\section{HPV Vaccines for Therapy}

Current HPV vaccines are prophylactic vaccines that do not treat pre-existing HPV infections and related conditions [44]. Researchers are working on therapeutic vaccines that trigger a cellular immune response as a treatment for established infections and malignancies [130]. There are large varieties of therapeutic vaccines, including bacterial-vector, viral-vector, peptide, nucleic acid, and cell-based 
vaccines, as well as combination therapies [131-136]. To date, unfortunately, with all the therapeutic vaccines tested, none of them could provide irreversible regression of HPV-associated cancers [137]. A randomized placebo-controlled clinical trial was approved recently to investigate the safety and efficacy of using a newly developed HPV type 16 E7-expressing Lactobacillus-based vaccine for the treatment of HPV16 positive HSIL [138]. Clinical trials that combined different therapeutic strategies, such as vaccines combined with a checkpoint inhibitor, showed promising results for the treatment of HPV-related cancers [139]. For example, combination therapy with antibodies against programmed death-ligand 1 (PD-L1) and HPV therapeutic vaccines have been reported to suppress tumor growth and increased immune-cell responses [140,141].

\section{Future Prospects}

HPV vaccines significantly decreased HPV infection and HPV related diseases. With the improvement in vaccine coverage and the introduction of pan-gender vaccination programs, better protection against HPV infections and fewer HPV-related cancer cases are expected. To achieve this, educational interventions introducing the risk of HPV and the benefits of vaccines are essential, especially in low- and middle- income counties. Decreased side effects with alternative adjuvants or other designs of vaccines will assist the acceptance and provision of vaccines at a young age. Another crucial problem is that the HPV types not covered by the vaccines are still at a high prevalence among young females [27,142]. The next-generation HPV vaccines should focus on high-valent vaccines with broad-protection spectrum. In addition, studies or clinical trials are essential to evaluate the impact of HPV vaccination on all HPV-related cancers. Therapeutic vaccines for cancer treatments are of great importance and entail a promising future aimed at combating HPV infection and related diseases from prevention to clearance.

Author Contributions: Writing—Original draft preparation, L.C., Y.W., and J.D.; writing—Review and editing, L.C., Y.W., and J.D. All authors have read and agreed to the published version of the manuscript.

Funding: J.D. is supported by the Swedish Foundation for Strategic Research (SSF) [ICA16-0050], Åke Wibergs Foundation [M18-0112], Jeanssons Foundation [JS2018-0034], Clas Groschinskys Minnesfond [M18213, M19351], Svenska Läkaresällskapet [SLS-784981], and the Karolinska Institutet.

Acknowledgments: We thank all the support from colleagues of Centre for Translational Microbiome Research (CTMR), Department of Microbiology, Tumor and Cell Biology, Karolinska Institutet, Sweden.

Conflicts of Interest: The authors declare no conflict of interest. The funders had no role in the design of the study; in the collection, analyses, or interpretation of data; in the writing of the manuscript, or in the decision to publish the results.

\section{References}

1. Brianti, P.; De Flammineis, E.; Mercuri, S.R. Review of HPV-related diseases and cancers. New Microbiol. 2017, 40, 80-85. [PubMed]

2. Näsman, A.; Du, J.; Dalianis, T. A global epidemic increase of an HPV-induced tonsil and tongue base cancer-Potential benefit from a pan-gender use of HPV vaccine. J. Intern. Med. 2020, 287, $134-152$. [CrossRef] [PubMed]

3. Leeds, I.L.; Fang, S.H. Anal cancer and intraepithelial neoplasia screening: A review. World J. Gastrointest. Surg. 2016, 8, 41-51. [CrossRef] [PubMed]

4. Tommasino, M. The human papillomavirus family and its role in carcinogenesis. Semin. Cancer Biol. 2014, 26, 13-21. [CrossRef] [PubMed]

5. Pastrana, D.V.; Peretti, A.; Welch, N.L.; Borgogna, C.; Olivero, C.; Badolato, R.; Notarangelo, L.D.; Gariglio, M.; FitzGerald, P.C.; McIntosh, C.E.; et al. Metagenomic Discovery of 83 New Human Papillomavirus Types in Patients with Immunodeficiency. mSphere 2018, 3, e00645-18. [CrossRef]

6. Athanasiou, A.; Bowden, S.; Paraskevaidi, M.; Fotopoulou, C.; Martin-Hirsch, P.; Paraskevaidis, E.; Kyrgiou, M. HPV vaccination and cancer prevention. Best Pract. Res. Clin. Obstet. Gynaecol. 2020, 65, 109-124. [CrossRef] [PubMed] 
7. Muñoz, N.; Bosch, F.X.; de Sanjosé, S.; Herrero, R.; Castellsagué, X.; Shah, K.V.; Snijders, P.J.; Meijer, C.J.; International Agency for Research on Cancer Multicenter Cervical Cancer Study Group. Epidemiologic classification of human papillomavirus types associated with cervical cancer. N. Engl. J. Med. 2003, 348, 518-527.

8. Bihl, M.P.; Tornillo, L.; Kind, A.B.; Obermann, E.; Noppen, C.; Chaffard, R.; Wynne, P.; Grilli, B.; Foerster, A.; Terracciano, L.M.; et al. Human papillomavirus (HPV) detection in cytologic specimens: Similarities and differences of available methodology. Appl. Immunohistochem. Mol. Morphol. 2017, 25, 184-189. [CrossRef]

9. Garland, S.M.; Kjaer, S.K.; Muñoz, N.; Block, S.L.; Brown, D.R.; DiNubile, M.J.; Lindsay, B.R.; Kuter, B.J.; Perez, G.; Dominiak-Felden, G.; et al. Impact and Effectiveness of the Quadrivalent Human Papillomavirus Vaccine: A Systematic Review of 10 Years of Real-world Experience. Clin. Infect. Dis. 2016, 63, 519-527. [CrossRef]

10. Herrero, R.; Quint, W.; Hildesheim, A.; Gonzalez, P.; Struijk, L.; Katki, H.A.; Porras, C.; Schiffman, M.; Rodriguez, A.C.; Solomon, D.; et al. Vaccine Group Reduced prevalence of oral human papillomavirus (HPV) 4 years after bivalent HPV vaccination in a randomized clinical trial in Costa Rica. PLoS ONE 2013, 8, e68329. [CrossRef]

11. Giuliano, A.R.; Palefsky, J.M.; Goldstone, S.; Moreira, E.D.; Penny, M.E.; Aranda, C.; Vardas, E.; Moi, H.; Jessen, H.; Hillman, R.; et al. Efficacy of quadrivalent HPV vaccine against HPV Infection and disease in males. N. Engl. J. Med. 2011, 364, 401-411. [CrossRef] [PubMed]

12. Schlecht, N.F.; Masika, M.; Diaz, A.; Nucci-Sack, A.; Salandy, A.; Pickering, S.; Strickler, H.D.; Shankar, V.; Burk, R.D. Risk of oral human papillomavirus infection among sexually active female adolescents receiving the quadrivalent vaccine. JAMA Netw. Open 2019, 2, e1914031. [CrossRef] [PubMed]

13. Wilkin, T.J.; Chen,H.; Cespedes, M.S.; Leon-Cruz,J.T.; Godfrey, C.; Chiao, E.Y.; Bastow, B.; Webster-Cyriaque, J.; Feng, Q.; Dragavon, J.; et al. A Randomized, Placebo-Controlled Trial of the Quadrivalent Human Papillomavirus Vaccine in Human Immunodeficiency Virus-Infected Adults Aged 27 Years or Older: AIDS Clinical Trials Group Protocol A5298. Clin. Infect. Dis. 2018, 67, 1339-1346. [CrossRef]

14. Olsson, S.E.; Kjaer, S.K.; Sigurdsson, K.; Iversen, O.E.; Hernandez-Avila, M.; Wheeler, C.M.; Perez, G.; Brown, D.R.; Koutsky, L.A.; Tay, E.H.; et al. Evaluation of quadrivalent HPV 6/11/16/18 vaccine efficacy against cervical and anogenital disease in subjects with serological evidence of prior vaccine type HPV infection. Hum. Vaccines 2009, 5, 696-704. [CrossRef] [PubMed]

15. Giuliano, A.R.; Joura, E.A.; Garland, S.M.; Huh, W.K.; Iversen, O.E.; Kjaer, S.K.; Ferenczy, A.; Kurman, R.J.; Ronnett, B.M.; Stoler, M.H.; et al. Nine-valent HPV vaccine efficacy against related diseases and definitive therapy: Comparison with historic placebo population. Gynecol. Oncol. 2019, 154, 110-117. [CrossRef] [PubMed]

16. Serrano, B.; Brotons, M.; Bosch, F.X.; Bruni, L. Epidemiology and burden of HPV-related disease. Best Pract. Res. Clin. Obstet. Gynaecol. 2018, 47, 14-26. [CrossRef]

17. Markowitz, L.E.; Drolet, M.; Perez, N.; Jit, M.; Brisson, M. Human papillomavirus vaccine effectiveness by number of doses: Systematic review of data from national immunization programs. Vaccine 2018, 36, 4806-4815. [CrossRef]

18. De Oliveira, C.M.; Fregnani, J.H.T.G.; Villa, L.L. HPV vaccine: Updates and highlights. Acta Cytol. 2019, 63, 159-168. [CrossRef]

19. World Health Organization. Human papillomavirus vaccines: WHO position paper, May 2017. Wkly. Epidemiol. Rec. 2017, 92, 241-268.

20. De Sanjose, S.; Quint, W.G.; Alemany, L.; Geraets, D.T.; Klaustermeier, J.E.; Lloveras, B.; Tous, S.; Felix, A.; Bravo, L.E.; Shin, H.R.; et al. Retrospective International Survey and HPV Time Trends Study Group Human papillomavirus genotype attribution in invasive cervical cancer: A retrospective cross-sectional worldwide study. Lancet Oncol. 2010, 11, 1048-1056. [CrossRef]

21. Garland, S.M.; Steben, M.; Sings, H.L.; James, M.; Lu, S.; Railkar, R.; Barr, E.; Haupt, R.M.; Joura, E.A. Natural history of genital warts: Analysis of the placebo arm of 2 randomized phase III trials of a quadrivalent human papillomavirus (types 6, 11, 16, and 18) vaccine. J. Infect. Dis. 2009, 199, 805-814. [CrossRef] [PubMed]

22. Yang, D.Y.; Bracken, K. Update on the new 9-valent vaccine for human papillomavirus prevention. Can. Fam. Physician. 2016, 62, 399-402. [PubMed] 
23. Canfell, K.; Kim, J.J.; Brisson, M.; Keane, A.; Simms, K.T.; Caruana, M.; Burger, E.A.; Martin, D.; Nguyen, D.T.N.; Bénard, É.; et al. Mortality impact of achieving WHO cervical cancer elimination targets: A comparative modelling analysis in 78 low-income and lower-middle-income countries. Lancet 2020, 395, 591-603. [CrossRef]

24. Bruni, L.; Diaz, M.; Barrionuevo-Rosas, L.; Herrero, R.; Bray, F.; Bosch, F.X.; de Sanjosé, S.; Castellsagué, X. Global estimates of human papillomavirus vaccination coverage by region and income level: A pooled analysis. Lancet Glob. Health 2016, 4, e453-e463. [CrossRef]

25. De Martel, C.; Plummer, M.; Vignat, J.; Franceschi, S. Worldwide burden of cancer attributable to HPV by site, country and HPV type. Int. J. Cancer 2017, 141, 664-670. [CrossRef] [PubMed]

26. Sabeena, S.; Bhat, P.V.; Kamath, V.; Arunkumar, G. Global human papilloma virus vaccine implementation: An update. J. Obstet. Gynaecol. Res. 2018, 44, 989-997. [CrossRef]

27. Ährlund-Richter, A.; Cheng, L.; Hu, Y.O.O.; Svensson, M.; Pennhag, A.A.L.; Ursu, R.G.; Haeggblom, L.; Grün, N.; Ramqvist, T.; Engstrand, L.; et al. Changes in cervical human papillomavirus (HPV) prevalence at a youth clinic in stockholm, sweden, a decade after the introduction of the HPV vaccine. Front. Cell Infect. Microbiol. 2019, 9, 59. [CrossRef]

28. LaMontagne, D.S.; Barge, S.; Le, N.T.; Mugisha, E.; Penny, M.E.; Gandhi, S.; Janmohamed, A.; Kumakech, E.; Mosqueira, N.R.; Nguyen, N.Q.; et al. Human papillomavirus vaccine delivery strategies that achieved high coverage in low- and middle-income countries. Bull. World Health Organ. 2011, 89, 821-830. [CrossRef]

29. Banerjee, A.V.; Duflo, E.; Glennerster, R.; Kothari, D. Improving immunisation coverage in rural India: Clustered randomised controlled evaluation of immunisation campaigns with and without incentives. BMJ 2010, 340, c2220. [CrossRef]

30. Zhou, J.; Sun, X.Y.; Stenzel, D.J.; Frazer, I.H. Expression of vaccinia recombinant HPV 16 L1 and L2 ORF proteins in epithelial cells is sufficient for assembly of HPV virion-like particles. Virology 1991, 185, 251-257. [CrossRef]

31. Kirnbauer, R.; Booy, F.; Cheng, N.; Lowy, D.R.; Schiller, J.T. Papillomavirus L1 major capsid protein self-assembles into virus-like particles that are highly immunogenic. Proc. Natl. Acad. Sci. USA 1992, 89, 12180-12184. [CrossRef] [PubMed]

32. Mitchell, T.C.; Casella, C.R. No pain no gain? Adjuvant effects of alum and monophosphoryl lipid A in pertussis and HPV vaccines. Curr. Opin. Immunol. 2017, 47, 17-25. [CrossRef] [PubMed]

33. Paz-Zulueta, M.; Álvarez-Paredes, L.; Rodríguez Díaz, J.C.; Parás-Bravo, P.; Andrada Becerra, M.E.; Rodríguez Ingelmo, J.M.; Ruiz García, M.M.; Portilla, J.; Santibañez, M. Prevalence of high-risk HPV genotypes, categorised by their quadrivalent and nine-valent HPV vaccination coverage, and the genotype association with high-grade lesions. BMC Cancer 2018, 18, 112. [CrossRef] [PubMed]

34. Schellenbacher, C.; Roden, R.; Kirnbauer, R. Chimeric L1-L2 virus-like particles as potential broad-spectrum human papillomavirus vaccines. J. Virol. 2009, 83, 10085-10095. [CrossRef] [PubMed]

35. Huber, B.; Schellenbacher, C.; Shafti-Keramat, S.; Jindra, C.; Christensen, N.; Kirnbauer, R. Chimeric L2-Based Virus-Like Particle (VLP) Vaccines Targeting Cutaneous Human Papillomaviruses (HPV). PLoS ONE 2017, 12, e0169533. [CrossRef] [PubMed]

36. Malagón, T.; Drolet, M.; Boily, M.C.; Franco, E.L.; Jit, M.; Brisson, J.; Brisson, M. Cross-protective efficacy of two human papillomavirus vaccines: A systematic review and meta-analysis. Lancet Infect. Dis. 2012, 12, 781-789. [CrossRef]

37. Schwarz, T.F.; Huang, L.M.; Valencia, A.; Panzer, F.; Chiu, C.H.; Decreux, A.; Poncelet, S.; Karkada, N.; Folschweiller, N.; Lin, L.; et al. A ten-year study of immunogenicity and safety of the AS04-HPV-16/18 vaccine in adolescent girls aged 10-14 years. Hum. Vaccines Immunother. 2019, 15, 1970-1979. [CrossRef]

38. Lehtinen, M.; Paavonen, J.; Wheeler, C.M.; Jaisamrarn, U.; Garland, S.M.; Castellsagué, X.; Skinner, S.R.; Apter, D.; Naud, P.; Salmerón, J.; et al. HPV PATRICIA Study Group Overall efficacy of HPV-16/18 AS04-adjuvanted vaccine against grade 3 or greater cervical intraepithelial neoplasia: 4-year end-of-study analysis of the randomised, double-blind PATRICIA trial. Lancet Oncol. 2012, 13, 89-99. [CrossRef]

39. Herrero, R.; Wacholder, S.; Rodríguez, A.C.; Solomon, D.; González, P.; Kreimer, A.R.; Porras, C.; Schussler, J.; Jiménez, S.; Sherman, M.E.; et al. Costa Rica Vaccine Trial Group Prevention of persistent human papillomavirus infection by an HPV16/18 vaccine: A community-based randomized clinical trial in Guanacaste, Costa Rica. Cancer Discov. 2011, 1, 408-419. [CrossRef] 
40. Castle, P.E.; Maza, M. Prophylactic HPV vaccination: Past, present, and future. Epidemiol. Infect. 2016, 144, 449-468. [CrossRef]

41. Harper, D.M.; DeMars, L.R. HPV vaccines-A review of the first decade. Gynecol. Oncol. 2017, 146, $196-204$. [CrossRef] [PubMed]

42. Draper, E.; Bissett, S.L.; Howell-Jones, R.; Waight, P.; Soldan, K.; Jit, M.; Andrews, N.; Miller, E.; Beddows, S. A randomized, observer-blinded immunogenicity trial of Cervarix $\left({ }^{\circledR}\right)$ and Gardasil $\left({ }^{\circledR}\right)$ Human Papillomavirus vaccines in 12-15 year old girls. PLoS ONE 2013, 8, e61825. [CrossRef] [PubMed]

43. Saadeh, K.; Park, I.; Gargano, J.W.; Whitney, E.; Querec, T.D.; Hurley, L.; Silverberg, M. Prevalence of human papillomavirus (HPV)-vaccine types by race/ethnicity and sociodemographic factors in women with high-grade cervical intraepithelial neoplasia (CIN2/3/AIS), Alameda County, California, United States. Vaccine 2020, 38, 39-45. [CrossRef]

44. Joura, E.A.; Giuliano, A.R.; Iversen, O.E.; Bouchard, C.; Mao, C.; Mehlsen, J.; Moreira, E.D.; Ngan, Y.; Petersen, L.K.; Lazcano-Ponce, E.; et al. Broad Spectrum HPV Vaccine Study A 9-valent HPV vaccine against infection and intraepithelial neoplasia in women. N. Engl. J. Med. 2015, 372, 711-723. [CrossRef] [PubMed]

45. Zhai, L.; Tumban, E. Gardasil-9: A global survey of projected efficacy. Antiviral. Res. 2016, 130, 101-109. [CrossRef] [PubMed]

46. Buchanan, T.R.; Graybill, W.S.; Pierce, J.Y. Morbidity and mortality of vulvar and vaginal cancers: Impact of 2-, 4-, and 9-valent HPV vaccines. Hum. Vaccines Immunother. 2016, 12, 1352-1356. [CrossRef] [PubMed]

47. Guevara, A.M.; Suarez, E.; Victoria, A.; Ngan, H.Y.; Hirschberg, A.L.; Fedrizzi, E.; Bautista, O.; Shields, C.; Joshi, A.; Luxembourg, A. Maternal transfer of anti HPV 6 and 11 antibodies upon immunization with the 9-valent HPV vaccine. Hum. Vaccines Immunother. 2019, 15, 141-145. [CrossRef]

48. Roden, R.B.S.; Stern, P.L. Opportunities and challenges for human papillomavirus vaccination in cancer. Nat. Rev. Cancer 2018, 18, 240-254. [CrossRef]

49. Drolet, M.; Bénard, É.; Pérez, N.; Brisson, M.; HPV Vaccination Impact Study Group. Population-level impact and herd effects following the introduction of human papillomavirus vaccination programmes: Updated systematic review and meta-analysis. Lancet 2019, 394, 497-509. [CrossRef]

50. Markowitz, L.E.; Hariri, S.; Lin, C.; Dunne, E.F.; Steinau, M.; McQuillan, G.; Unger, E.R. Reduction in human papillomavirus (HPV) prevalence among young women following HPV vaccine introduction in the United States, National Health and Nutrition Examination Surveys, 2003-2010. J. Infect. Dis. 2013, 208, 385-393. [CrossRef]

51. Taira, A.V.; Neukermans, C.P.; Sanders, G.D. Evaluating human papillomavirus vaccination programs. Emerg. Infect. Dis. 2004, 10, 1915-1923. [CrossRef] [PubMed]

52. Baussano, I.; Lazzarato, F.; Brisson, M.; Franceschi, S. Human papillomavirus vaccination at a time of changing sexual behavior. Emerg. Infect. Dis. 2016, 22, 18-23. [CrossRef] [PubMed]

53. Li, N.; Franceschi, S.; Howell-Jones, R.; Snijders, P.J.; Clifford, G.M. Human papillomavirus type distribution in 30,848 invasive cervical cancers worldwide: Variation by geographical region, histological type and year of publication. Int. J. Cancer 2011, 128, 927-935. [CrossRef] [PubMed]

54. Clifford, G.M.; Smith, J.S.; Plummer, M.; Muñoz, N.; Franceschi, S. Human papillomavirus types in invasive cervical cancer worldwide: A meta-analysis. Br. J. Cancer 2003, 88, 63-73. [CrossRef] [PubMed]

55. Ogembo, R.K.; Gona, P.N.; Seymour, A.J.; Park, H.S.; Bain, P.A.; Maranda, L.; Ogembo, J.G. Prevalence of human papillomavirus genotypes among African women with normal cervical cytology and neoplasia: A systematic review and meta-analysis. PLoS ONE 2015, 10, e0122488. [CrossRef]

56. Hirth, J. Disparities in HPV vaccination rates and HPV prevalence in the United States: A review of the literature. Hum. Vaccines Immunother. 2019, 15, 146-155. [CrossRef]

57. Gelman, A.; Miller, E.; Schwarz, E.B.; Akers, A.Y.; Jeong, K.; Borrero, S. Racial disparities in human papillomavirus vaccination: Does access matter? J. Adolesc. Health 2013, 53, 756-762. [CrossRef] [PubMed]

58. Spencer, J.C.; Calo, W.A.; Brewer, N.T. Disparities and reverse disparities in HPV vaccination: A systematic review and meta-analysis. Prev. Med. 2019, 123, 197-203. [CrossRef]

59. Dixon, B.E.; Zimet, G.D.; Xiao, S.; Tu, W.; Lindsay, B.; Church, A.; Downs, S.M. An educational intervention to improve HPV vaccination: A cluster randomized trial. Pediatrics 2019, 143. [CrossRef]

60. Thompson, B.; Barrington, W.E.; Briant, K.J.; Kupay, E.; Carosso, E.; Gonzalez, N.E.; Gonzalez, V.J. Educating Latinas about cervical cancer and HPV: A pilot randomized study. Cancer Causes Control 2019, 30, 375-384. [CrossRef] 
61. Cory, L.; Cha, B.; Ellenberg, S.; Bogner, H.R.; Hwang, W.T.; Smith, J.S.; Haggerty, A.; Morgan, M.; Burger, R.; $\mathrm{Chu}, \mathrm{C}$; et al. Effects of educational interventions on human papillomavirus vaccine acceptability: A randomized controlled trial. Obstet. Gynecol. 2019, 134, 376-384. [CrossRef] [PubMed]

62. Larasati, L.; Afiyanti, Y.; Rahmah, H.; Milanti, A. Women's knowledge, beliefs, and behaviors toward the prevention of human papillomavirus transmission. Enfermería Clínica 2018, 28, 191-194. [CrossRef]

63. Brewer, N.T.; Hall, M.E.; Malo, T.L.; Gilkey, M.B.; Quinn, B.; Lathren, C. Announcements versus conversations to improve HPV vaccination coverage: A randomized trial. Pediatrics 2017, 139. [CrossRef] [PubMed]

64. Dempsey, A.F.; Pyrznawoski, J.; Lockhart, S.; Barnard, J.; Campagna, E.J.; Garrett, K.; Fisher, A.; Dickinson, L.M.; O'Leary, S.T. Effect of a health care professional communication training intervention on adolescent human papillomavirus vaccination: A cluster randomized clinical trial. JAMA Pediatr. 2018, 172, e180016. [CrossRef]

65. Herrera-Ortiz, A.; Conde-Glez, C.J.; Olamendi-Portugal, M.L.; García-Cisneros, S.; Plett-Torres, T.; Sánchez-Alemán, M.A. College women, HPV genotyping and sexual behavior before HPV vaccination: Results from samples stored for a long time. J. Infect. Public Health 2018, 11, 286-289. [CrossRef]

66. Karlsson, R.; Jonsson, M.; Edlund, K.; Evander, M.; Gustavsson, A.; Bodén, E.; Rylander, E.; Wadell, G. Lifetime number of partners as the only independent risk factor for human papillomavirus infection: A population-based study. Sex. Transm. Dis. 1995, 22, 119-127. [CrossRef]

67. Vaccarella, S.; Franceschi, S.; Herrero, R.; Muñoz, N.; Snijders, P.J.; Clifford, G.M.; Smith, J.S.; Lazcano-Ponce, E.; Sukvirach, S.; Shin, H.R.; et al. IARC HPV Prevalence Surveys Study Group Sexual behavior, condom use, and human papillomavirus: Pooled analysis of the IARC human papillomavirus prevalence surveys. Cancer Epidemiol. Biomarkers Prev. 2006, 15, 326-333. [CrossRef]

68. Chelimo, C.; Wouldes, T.A.; Cameron, L.D.; Elwood, J.M. Risk factors for and prevention of human papillomaviruses (HPV), genital warts and cervical cancer. J. Infect. 2013, 66, 207-217. [CrossRef]

69. Chan, J.K.; Monk, B.J.; Brewer, C.; Keefe, K.A.; Osann, K.; McMeekin, S.; Rose, G.S.; Youssef, M.; Wilczynski, S.P.; Meyskens, F.L.; et al. HPV infection and number of lifetime sexual partners are strong predictors for "natural" regression of CIN 2 and 3. Br. J. Cancer 2003, 89, 1062-1066. [CrossRef]

70. Agénor, M.; McCauley, H.L.; Peitzmeier, S.M.; Haneuse, S.; Gordon, A.R.; Potter, J.; Austin, S.B. Sex of sexual partners and human papillomavirus vaccination among U.S. girls and women. Am. J. Prev. Med. 2016, 50, 318-327. [CrossRef]

71. Brouwer, A.F.; Delinger, R.L.; Eisenberg, M.C.; Campredon, L.P.; Walline, H.M.; Carey, T.E.; Meza, R. HPV vaccination has not increased sexual activity or accelerated sexual debut in a college-aged cohort of men and women. BMC Public Health 2019, 19, 821. [CrossRef] [PubMed]

72. Bogaards, J.A.; Wallinga, J.; Brakenhoff, R.H.; Meijer, C.J.; Berkhof, J. Direct benefit of vaccinating boys along with girls against oncogenic human papillomavirus: Bayesian evidence synthesis. BMJ 2015, 350, h2016. [CrossRef] [PubMed]

73. World Health Organization. Comprehensive cervical cancer control: A guide to essential practice. In WHO Guidelines Approved by the Guidelines Review Committee; World Health Organization: Geneva, Switzerland, 2014.

74. Petrosky, E.; Bocchini, J.A.; Hariri, S.; Chesson, H.; Curtis, C.R.; Saraiya, M.; Unger, E.R.; Markowitz, L.E.; Centers for Disease Control and Prevention (CDC). Use of 9-valent human papillomavirus (HPV) vaccine: Updated HPV vaccination recommendations of the advisory committee on immunization practices. MMWR Morb. Mortal. Wkly. Rep. 2015, 64, 300-304. [PubMed]

75. Elfström, K.M.; Lazzarato, F.; Franceschi, S.; Dillner, J.; Baussano, I. Human Papillomavirus Vaccination of Boys and Extended Catch-up Vaccination: Effects on the Resilience of Programs. J. Infect. Dis. 2016, 213, 199-205. [CrossRef]

76. Sonawane, K.; Suk, R.; Chiao, E.Y.; Chhatwal, J.; Qiu, P.; Wilkin, T.; Nyitray, A.G.; Sikora, A.G.; Deshmukh, A.A. Oral human papillomavirus infection: Differences in prevalence between sexes and concordance with genital human papillomavirus infection, NHANES 2011 to 2014. Ann. Intern. Med. 2017, 167, 714-724. [CrossRef]

77. Ferlay, J.; Soerjomataram, I.; Ervik, M.; Dikshit, R.; Bray, F. GLOBOCAN 2012 v1.0, Cancer Incidence and Mortality Worldwide: IARC Cancer Base No. 11; International Agency for Research on Cancer: Lyon, France, 2014.

78. D'Souza, G.; McNeel, T.S.; Fakhry, C. Understanding personal risk of oropharyngeal cancer: Risk-groups for oncogenic oral HPV infection and oropharyngeal cancer. Ann. Oncol. 2017, 28, 3065-3069. [CrossRef] 
79. Schwartz, S.M.; Daling, J.R.; Doody, D.R.; Wipf, G.C.; Carter, J.J.; Madeleine, M.M.; Mao, E.J.; Fitzgibbons, E.D.; Huang, S.; Beckmann, A.M.; et al. Oral cancer risk in relation to sexual history and evidence of human papillomavirus infection. J. Natl. Cancer Inst. 1998, 90, 1626-1636. [CrossRef]

80. Gillison, M.L.; Koch, W.M.; Capone, R.B.; Spafford, M.; Westra, W.H.; Wu, L.; Zahurak, M.L.; Daniel, R.W.; Viglione, M.; Symer, D.E.; et al. Evidence for a causal association between human papillomavirus and a subset of head and neck cancers. J. Natl. Cancer Inst. 2000, 92, 709-720. [CrossRef] [PubMed]

81. Balz, V.; Scheckenbach, K.; Götte, K.; Bockmühl, U.; Petersen, I.; Bier, H. Is the p53 inactivation frequency in squamous cell carcinomas of the head and neck underestimated? Analysis of p53 exons 2-11 and human papillomavirus 16/18 E6 transcripts in 123 unselected tumor specimens. Cancer Res. 2003, 63, 1188-1191.

82. Brandwein, M.; Zeitlin, J.; Nuovo, G.J.; MacConnell, P.; Bodian, C.; Urken, M.; Biller, H. HPV detection using "hot start" polymerase chain reaction in patients with oral cancer: A clinicopathological study of 64 patients. Mod. Pathol. 1994, 7, 720-727.

83. Klussmann, J.P.; Gültekin, E.; Weissenborn, S.J.; Wieland, U.; Dries, V.; Dienes, H.P.; Eckel, H.E.; Pfister, H.J.; Fuchs, P.G. Expression of p16 protein identifies a distinct entity of tonsillar carcinomas associated with human papillomavirus. Am. J. Pathol. 2003, 162, 747-753. [CrossRef]

84. Nordfors, C.; Vlastos, A.; Du, J.; Ahrlund-Richter, A.; Tertipis, N.; Grün, N.; Romanitan, M.; Haeggblom, L.; Roosaar, A.; Dahllöf, G.; et al. Human papillomavirus prevalence is high in oral samples of patients with tonsillar and base of tongue cancer. Oral Oncol. 2014, 50, 491-497. [CrossRef] [PubMed]

85. De Vuyst, H.; Clifford, G.M.; Nascimento, M.C.; Madeleine, M.M.; Franceschi, S. Prevalence and type distribution of human papillomavirus in carcinoma and intraepithelial neoplasia of the vulva, vagina and anus: A meta-analysis. Int. J. Cancer 2009, 124, 1626-1636. [CrossRef]

86. Salati, S.A.; Al Kadi, A. Anal cancer-A review. Int. J. Health Sci. 2012, 6, 206-230. [CrossRef]

87. D'Souza, G.; Dempsey, A. The role of HPV in head and neck cancer and review of the HPV vaccine. Prev. Med. 2011, 53 (Suppl. S1), S5-S11.

88. Syrjänen, S.; Rautava, J. Vaccination expectations in HNSCC. Recent Results Cancer Res. 2017, 206, $257-267$.

89. Prue, G.; Baker, P.; Graham, D.; Nutting, C.; Greenhouse, P.; Lawler, M. It is time for universal HPV vaccination. Lancet 2018, 392, 913-914. [CrossRef]

90. Kirby, T. MSM in England to be offered free HPV vaccination. Lancet Oncol. 2018, 19, e148. [CrossRef]

91. Chesson, H.W.; Ekwueme, D.U.; Saraiya, M.; Dunne, E.F.; Markowitz, L.E. The cost-effectiveness of male HPV vaccination in the United States. Vaccine 2011, 29, 8443-8450. [CrossRef]

92. Kim, J.J.; Goldie, S.J. Health and economic implications of HPV vaccination in the United States. N. Engl. J. Med. 2008, 359, 821-832. [CrossRef]

93. Datta, S.; Pink, J.; Medley, G.F.; Petrou, S.; Staniszewska, S.; Underwood, M.; Sonnenberg, P.; Keeling, M.J. Assessing the cost-effectiveness of HPV vaccination strategies for adolescent girls and boys in the UK. BMC Infect. Dis. 2019, 19, 552. [CrossRef]

94. Centers for Disease Control and Prevention (CDC). Human papillomavirus vaccination coverage among adolescent girls, 2007-2012, and postlicensure vaccine safety monitoring, 2006-2013-United States. MMWR Morb. Mortal Wkly. Rep. 2013, 62, 591-595.

95. Gee, J.; Naleway, A.; Shui, I.; Baggs, J.; Yin, R.; Li, R.; Kulldorff, M.; Lewis, E.; Fireman, B.; Daley, M.F.; et al. Monitoring the safety of quadrivalent human papillomavirus vaccine: Findings from the Vaccine Safety Datalink. Vaccine 2011, 29, 8279-8284. [CrossRef] [PubMed]

96. Gee, J.; Weinbaum, C.; Sukumaran, L.; Markowitz, L.E. Quadrivalent HPV vaccine safety review and safety monitoring plans for nine-valent HPV vaccine in the United States. Hum. Vaccines Immunother. 2016, 12, 1406-1417. [CrossRef] [PubMed]

97. Phillips, A.; Patel, C.; Pillsbury, A.; Brotherton, J.; Macartney, K. Safety of human papillomavirus vaccines: An updated review. Drug Saf. 2018, 41, 329-346. [CrossRef] [PubMed]

98. Ferris, D.G.; Samakoses, R.; Block, S.L.; Lazcano-Ponce, E.; Restrepo, J.A.; Mehlsen, J.; Chatterjee, A.; Iversen, O.E.; Joshi, A.; Chu, J.L.; et al. 4-Valent Human Papillomavirus (4vHPV) Vaccine in Preadolescents and Adolescents After 10 Years. Pediatrics 2017, 140, e20163947. [CrossRef]

99. Huh, W.K.; Joura, E.A.; Giuliano, A.R.; Iversen, O.E.; de Andrade, R.P.; Ault, K.A.; Bartholomew, D.; Cestero, R.M.; Fedrizzi, E.N.; Hirschberg, A.L.; et al. Final efficacy, immunogenicity, and safety analyses of a nine-valent human papillomavirus vaccine in women aged 16-26 years: A randomised, double-blind trial. Lancet 2017, 390, 2143-2159. [CrossRef] 
100. Gonçalves, A.K.; Cobucci, R.N.; Rodrigues, H.M.; de Melo, A.G.; Giraldo, P.C. Safety, tolerability and side effects of human papillomavirus vaccines: A systematic quantitative review. Braz. J. Infect. Dis. 2014, 18, 651-659. [CrossRef]

101. Paavonen, J.; Jenkins, D.; Bosch, F.X.; Naud, P.; Salmerón, J.; Wheeler, C.M.; Chow, S.N.; Apter, D.L.; Kitchener, H.C.; Castellsague, X.; et al. HPV PATRICIA study group Efficacy of a prophylactic adjuvanted bivalent L1 virus-like-particle vaccine against infection with human papillomavirus types 16 and 18 in young women: An interim analysis of a phase III double-blind, randomised controlled trial. Lancet 2007, 369, 2161-2170. [CrossRef]

102. Martínez-Lavín, M. Hypothesis: Human papillomavirus vaccination syndrome-small fiber neuropathy and dysautonomia could be its underlying pathogenesis. Clin. Rheumatol. 2015, 34, 1165-1169. [CrossRef]

103. Ozawa, K.; Hineno, A.; Kinoshita, T.; Ishihara, S.; Ikeda, S.I. Suspected adverse effects after human papillomavirus vaccination: A temporal relationship between vaccine administration and the appearance of symptoms in Japan. Drug Saf. 2017, 40, 1219-1229. [CrossRef] [PubMed]

104. Ikeda, S.I.; Hineno, A.; Ozawa, K.; Kinoshita, T. Suspected adverse effects after human papillomavirus vaccination: A temporal relationship. Immunol. Res. 2018, 66, 723-725. [CrossRef] [PubMed]

105. Descamps, D.; Hardt, K.; Spiessens, B.; Izurieta, P.; Verstraeten, T.; Breuer, T.; Dubin, G. Safety of human papillomavirus (HPV)-16/18 AS04-adjuvanted vaccine for cervical cancer prevention: A pooled analysis of 11 clinical trials. Hum. Vaccines 2009, 5, 332-340. [CrossRef]

106. Martínez-Lavín, M. Fibromyalgia-Like Illness in 2 Girls After Human Papillomavirus Vaccination. J. Clin. Rheumatol. 2014, 20, 392-393. [CrossRef] [PubMed]

107. Arnheim-Dahlström, L.; Pasternak, B.; Svanström, H.; Sparén, P.; Hviid, A. Autoimmune, neurological, and venous thromboembolic adverse events after immunisation of adolescent girls with quadrivalent human papillomavirus vaccine in Denmark and Sweden: Cohort study. BMJ 2013, 347, f5906. [CrossRef] [PubMed]

108. Chen, J.; Gopala, K.; Akarsh, P.K.; Struyf, F.; Rosillon, D. Prevalence and Incidence of Human Papillomavirus (HPV) Infection Before and After Pregnancy: Pooled Analysis of the Control Arms of Efficacy Trials of HPV-16/18 AS04-Adjuvanted Vaccine. Open Forum Infect. Dis. 2019, 6, ofz486. [CrossRef]

109. Spinner, C.; Ding, L.; Bernstein, D.I.; Brown, D.R.; Franco, E.L.; Covert, C.; Kahn, J.A. Human papillomavirus vaccine effectiveness and herd protection in young women. Pediatrics 2019, 143, e20181902. [CrossRef]

110. FUTURE II Study Group. Quadrivalent vaccine against human papillomavirus to prevent high-grade cervical lesions. N. Engl. J. Med. 2007, 356, 1915-1927. [CrossRef]

111. Garland, S.M.; Hernandez-Avila, M.; Wheeler, C.M.; Perez, G.; Harper, D.M.; Leodolter, S.; Tang, G.W.; Ferris, D.G.; Steben, M.; Bryan, J.; et al. Females United to Unilaterally Reduce Endo/Ectocervical Disease (FUTURE) I Investigators Quadrivalent vaccine against human papillomavirus to prevent anogenital diseases. N. Engl. J. Med. 2007, 356, 1928-1943. [CrossRef]

112. Joura, E.A.; Leodolter, S.; Hernandez-Avila, M.; Wheeler, C.M.; Perez, G.; Koutsky, L.A.; Garland, S.M.; Harper, D.M.; Tang, G.W.; Ferris, D.G.; et al. Efficacy of a quadrivalent prophylactic human papillomavirus (types 6, 11, 16, and 18) L1 virus-like-particle vaccine against high-grade vulval and vaginal lesions: A combined analysis of three randomised clinical trials. Lancet 2007, 369, 1693-1702. [CrossRef]

113. Palefsky, J.M.; Giuliano, A.R.; Goldstone, S.; Moreira, E.D.; Aranda, C.; Jessen, H.; Hillman, R.; Ferris, D.; Coutlee, F.; Stoler, M.H.; et al. HPV vaccine against anal HPV infection and anal intraepithelial neoplasia. N. Engl. J. Med. 2011, 365, 1576-1585. [CrossRef] [PubMed]

114. Paavonen, J.; Naud, P.; Salmerón, J.; Wheeler, C.M.; Chow, S.N.; Apter, D.; Kitchener, H.; Castellsague, X.; Teixeira, J.C.; Skinner, S.R.; et al. HPV PATRICIA Study Group Efficacy of human papillomavirus (HPV)-16/18 AS04-adjuvanted vaccine against cervical infection and precancer caused by oncogenic HPV types (PATRICIA): Final analysis of a double-blind, randomised study in young women. Lancet 2009, 374, 301-314. [CrossRef]

115. Schwarz, T.F. Clinical update of the AS04-adjuvanted human papillomavirus-16/18 cervical cancer vaccine, Cervarix. Adv. Ther. 2009, 26, 983-998. [CrossRef]

116. Machalek, D.A.; Garland, S.M.; Brotherton, J.M.L.; Bateson, D.; McNamee, K.; Stewart, M.; Rachel Skinner, S.; Liu, B.; Cornall, A.M.; Kaldor, J.M.; et al. Very Low Prevalence of Vaccine Human Papillomavirus Types Among 18- to 35-Year Old Australian Women 9 Years Following Implementation of Vaccination. J. Infect. Dis. 2018, 217, 1590-1600. [CrossRef] [PubMed] 
117. Read, T.R.; Hocking, J.S.; Chen, M.Y.; Donovan, B.; Bradshaw, C.S.; Fairley, C.K. The near disappearance of genital warts in young women 4 years after commencing a national human papillomavirus (HPV) vaccination programme. Sex. Transm. Infect. 2011, 87, 544-547. [CrossRef] [PubMed]

118. Nsouli-Maktabi, H.; Ludwig, S.L.; Yerubandi, U.D.; Gaydos, J.C. Incidence of genital warts among U.S. service members before and after the introduction of the quadrivalent human papillomavirus vaccine. MSMR 2013, 20, 17-20. [PubMed]

119. Brotherton, J.M.; Fridman, M.; May, C.L.; Chappell, G.; Saville, A.M.; Gertig, D.M. Early effect of the HPV vaccination programme on cervical abnormalities in Victoria, Australia: An ecological study. Lancet 2011, 377, 2085-2092. [CrossRef]

120. Crowe, E.; Pandeya, N.; Brotherton, J.M.; Dobson, A.J.; Kisely, S.; Lambert, S.B.; Whiteman, D.C. Effectiveness of quadrivalent human papillomavirus vaccine for the prevention of cervical abnormalities: Case-control study nested within a population based screening programme in Australia. BMJ 2014, 348, g1458. [CrossRef] [PubMed]

121. Murillo, R.; Ordóñez-Reyes, C. Human papillomavirus (HPV) vaccination: From clinical studies to immunization programs. Int. J. Gynecol. Cancer 2019, 29, 1317-1326. [CrossRef]

122. Lin, L.; Macias Parra, M.; Sierra, V.Y.; Salas Cespedes, A.; Granados, M.A.; Luque, A.; Karkada, N.; Castrejon Alba, M.M.; Romano-Mazzotti, L.; Borys, D.; et al. Long-term Immunogenicity and Safety of the AS04-adjuvanted Human Papillomavirus-16/18 Vaccine in Four- to Six-year-old Girls: Three-year Follow-up of a Randomized Phase III Trial. Pediatr. Infect. Dis. J. 2019, 38, 1061-1067. [CrossRef]

123. Bergman, H.; Buckley, B.S.; Villanueva, G.; Petkovic, J.; Garritty, C.; Lutje, V.; Riveros-Balta, A.X.; Low, N.; Henschke, N. Comparison of different human papillomavirus (HPV) vaccine types and dose schedules for prevention of HPV-related disease in females and males. Cochrane Database Syst. Rev. 2019, 2019, CD013479. [CrossRef] [PubMed]

124. Basu, P.; Muwonge, R.; Bhatla, N.; Nene, B.M.; Joshi, S.; Esmy, P.O.; Poli, U.R.R.; Joshi, G.; Verma, Y.; Zomawia, E.; et al. Indian HPV vaccine study group Two-dose recommendation for Human Papillomavirus vaccine can be extended up to 18 years-Updated evidence from Indian follow-up cohort study. Papillomavirus Res. 2019, 7, 75-81. [CrossRef]

125. Sappenfield, E.; Jamieson, D.J.; Kourtis, A.P. Pregnancy and susceptibility to infectious diseases. Infect. Dis. Obstet. Gynecol. 2013, 2013, 752852. [CrossRef] [PubMed]

126. International Collaboration of Epidemiological Studies of Cervical Cancer. Cervical carcinoma and reproductive factors: Collaborative reanalysis of individual data on 16,563 women with cervical carcinoma and 33,542 women without cervical carcinoma from 25 epidemiological studies. Int. J. Cancer 2006, 119, 1108-1124. [CrossRef]

127. Arbyn, M.; Xu, L.; Simoens, C.; Martin-Hirsch, P.P. Prophylactic vaccination against human papillomaviruses to prevent cervical cancer and its precursors. Cochrane Database Syst. Rev. 2018, 5, CD009069. [CrossRef] [PubMed]

128. Trottier, H.; Mayrand, M.H.; Baggio, M.L.; Galan, L.; Ferenczy, A.; Villa, L.L.; Franco, E.L.; Ludwig-McGill Cohort Study Group. Risk of Human Papillomavirus (HPV) Infection and Cervical Neoplasia after Pregnancy. BMC Pregnancy Childbirth 2015, 15, 244. [CrossRef] [PubMed]

129. Schmeink, C.E.; Melchers, W.J.; Hendriks, J.C.; Quint, W.G.; Massuger, L.F.; Bekkers, R.L. Human papillomavirus detection in pregnant women: A prospective matched cohort study. J. Womens Health (Larchmt) 2012, 21, 1295-1301. [CrossRef]

130. Chabeda, A.; Yanez, R.J.R.; Lamprecht, R.; Meyers, A.E.; Rybicki, E.P.; Hitzeroth, I.I. Therapeutic vaccines for high-risk HPV-associated diseases. Papillomavirus Res. 2018, 5, 46-58. [CrossRef]

131. Maciag, P.C.; Radulovic, S.; Rothman, J. The first clinical use of a live-attenuated Listeria monocytogenes vaccine: A Phase I safety study of Lm-LLO-E7 in patients with advanced carcinoma of the cervix. Vaccine 2009, 27, 3975-3983. [CrossRef]

132. Hung, C.F.; Ma, B.; Monie, A.; Tsen, S.W.; Wu, T.C. Therapeutic human papillomavirus vaccines: Current clinical trials and future directions. Expert. Opin. Biol. Ther. 2008, 8, 421-439. [CrossRef]

133. Corson, S.L. Vaccination against HPV-16 Oncoproteins in Vulvar Intraepithelial Neoplasia. J. Minim. Invasive Gynecol. 2010, 17, 269. [CrossRef] 
134. Kim, T.J.; Jin, H.T.; Hur, S.Y.; Yang, H.G.; Seo, Y.B.; Hong, S.R.; Lee, C.W.; Kim, S.; Woo, J.W.; Park, K.S.; et al. Clearance of persistent HPV infection and cervical lesion by therapeutic DNA vaccine in CIN3 patients. Nat. Commun. 2014, 5, 5317. [CrossRef]

135. Santin, A.D.; Bellone, S.; Palmieri, M.; Zanolini, A.; Ravaggi, A.; Siegel, E.R.; Roman, J.J.; Pecorelli, S.; Cannon, M.J. Human papillomavirus type 16 and 18 E7-pulsed dendritic cell vaccination of stage IB or IIA cervical cancer patients: A phase I escalating-dose trial. J. Virol. 2008, 82, 1968-1979. [CrossRef] [PubMed]

136. Alvarez, R.D.; Huh, W.K.; Bae, S.; Lamb, L.S.; Conner, M.G.; Boyer, J.; Wang, C.; Hung, C.F.; Sauter, E.; Paradis, M.; et al. A pilot study of pNGVL4a-CRT/E7(detox) for the treatment of patients with HPV16+ cervical intraepithelial neoplasia 2/3 (CIN2/3). Gynecol. Oncol. 2016, 140, 245-252. [CrossRef] [PubMed]

137. Vonsky, M.S.; Runov, A.L.; Gordeychuk, I.V.; Isaguliants, M.G. Therapeutic vaccines against human papilloma viruses: Achievements and prospects. Biochem. Mosc. 2019, 84, 800-816. [CrossRef] [PubMed]

138. Ikeda, Y.; Uemura, Y.; Asai-Sato, M.; Nakao, T.; Nakajima, T.; Iwata, T.; Akiyama, A.; Satoh, T.; Yahata, H.; Kato, K.; et al. Safety and efficacy of mucosal immunotherapy using human papillomavirus (HPV) type 16 E7-expressing Lactobacillus-based vaccine for the treatment of high-grade squamous intraepithelial lesion (HSIL): The study protocol of a randomized placebo-controlled clinical trial (MILACLE study). Jpn. J. Clin. Oncol. 2019, 49, 877-880. [PubMed]

139. Shibata, T.; Lieblong, B.J.; Sasagawa, T.; Nakagawa, M. The promise of combining cancer vaccine and checkpoint blockade for treating HPV-related cancer. Cancer Treat Rev. 2019, 78, 8-16. [CrossRef]

140. Chandra, J.; Dutton, J.L.; Li, B.; Woo, W.P.; Xu, Y.; Tolley, L.K.; Yong, M.; Wells, J.W.; R Leggatt, G.; Finlayson, N.; et al. DNA Vaccine Encoding HPV16 Oncogenes E6 and E7 Induces Potent Cell-mediated and Humoral Immunity Which Protects in Tumor Challenge and Drives E7-expressing Skin Graft Rejection. J. Immunother. 2017, 40, 62-70. [CrossRef]

141. Dorta-Estremera, S.; Chin, R.L.; Sierra, G.; Nicholas, C.; Yanamandra, A.V.; Nookala, S.M.K.; Yang, G.; Singh, S.; Curran, M.A.; Sastry, K.J. Mucosal HPV E6/E7 Peptide Vaccination in Combination with Immune Checkpoint Modulation Induces Regression of HPV+ Oral Cancers. Cancer Res. 2018, 78, 5327-5339. [CrossRef]

142. Tota, J.E.; Ramanakumar, A.V.; Jiang, M.; Dillner, J.; Walter, S.D.; Kaufman, J.S.; Coutlée, F.; Villa, L.L.; Franco, E.L. Epidemiologic approaches to evaluating the potential for human papillomavirus type replacement postvaccination. Am. J. Epidemiol. 2013, 178, 625-634. [CrossRef]

(C) 2020 by the authors. Licensee MDPI, Basel, Switzerland. This article is an open access article distributed under the terms and conditions of the Creative Commons Attribution (CC BY) license (http://creativecommons.org/licenses/by/4.0/). 